\title{
An Investigation of the Relationship between Iranian EFL Learners' Cultural Intelligence and Their Performance on the IELTS Listening Modules
}

\author{
Arezoo Rafie \\ English Department, University of Zanjan, Iran \\ E-mail: arezoo.rafie24@gmail.com \\ Robab Khosravi (Corresponding author) \\ English Language Department, University of Zanjan, P. O. Box 45195-313, Zanjan, Iran \\ E-mail: rkhosravi@znu.ac.ir \\ Mahdi Nasiri \\ English Language Department, University of Zanjan, P. O. Box 45195-313, Zanjan, Iran \\ E-mail: mahdinasiri@znu.ac.ir
}

Doi:10.7575/aiac.alls.v.7n.3p.13

URL: http://dx.doi.org/10.7575/aiac.alls.v.7n.3p.13
Received: 05/01/2016

Accepted: 19/02/2016

\begin{abstract}
This study aimed to investigate the relationship between Iranian EFL Learners' Cultural intelligence (CQ) and their performance on the IELTS Listening Module. Sixty advanced EFL students majoring in English translation at University of Zanjan were matched for the study through the Oxford Quick Placement Test. Cultural Intelligence Scale developed and validated by Ang et al. (2007) was used to assess the participants' cultural intelligence. The IELTS Listening Module and the Cultural Intelligence Scale were administered to the participants who were willing to take part in this study. The correlational analysis of the results revealed that there exists a statistically significant relationship between EFL learners' CQ and their performance on IELTS Listening Module. Furthermore, running multiple regression analysis indicated that of the four components of CQ (i.e. metacognitive, cognitive, behavioral, and motivational CQs), motivational CQ is the best predictor forthe listening ability of EFL learners. The findings of the study highlight the importance of incorporating programs for teaching culture in the EFL classroom, as enhancing cultural intelligence related skills at schools and universities can promote better communicational skills.
\end{abstract}

Keywords: Culture, cultural intelligence (CQ), teaching culture, listening comprehension, EFL learners

\section{Introduction}

Inarguably, nowadays English is used as a lingua franca, a common means of communication between peoples of various languages and cultures. In such context, cultural knowledge is considered not only as an indispensable aspect of communicative competence, but also an integral aspect of second language pedagogy. In other words, learning the target language's culture has proved to be both the means and ends for language teaching. Attempting to learn a new language, learners are expected to familiarize themselves with the target culture in order to become proficient in that language. Some EFL learners may not be adequately knowledgeable or familiar with the cultural norms of the target language; this may result in an invisible communicative barrier that considerably affects their communication skills. In this regard, for the students who learn English as a foreign language, curriculum designers should incorporate sufficient materials in the course books so as to enhance the students' cultural competence.

Increasing EFL learners' cultural intelligence (CQ) can facilitate the learning process in the English classroom. Cultural intelligence is defined as the individual's ability to function effectively in multicultural environments. The reason for including teaching culture in the curricula is because it provides teachers and learners with an insight to cultural norms and differences. In fact, enhancing the students' CQ not only promotes better communicative skills, but also facilitates academic success.

On the other hand, listening comprehension is a complex process and crucial in the development of foreign language competence. While the importance of CQ in learning a foreign (or a second) language is emphasized by language teachers and curriculum designers, studies that exclusively address the relationship between CQ and receptive skills such as listening and reading are not many in the Iranian context. This study investigates the relationship between Iranian EFL learner's cultural intelligence and their performance on the IELTS listening module. 


\section{Previous Studies}

\subsection{The Importance of Culture in Language Teaching}

What is the definition of culture in general, and its place in language teaching in particular? Giroux (2000) defines culture as "the site where identities are constructed, desires mobilized, and moral values shaped." (p. 132). Richards and Schmidt consider culture as "the set of practices, codes and values that mark a particular nation or group: the sum of a nation or group's most highly thought of works of literature, art, music, etc." (2010, p. 151). Some scholars, (Chastain, 1988; Thanasoulas, 2001, Kramsch, 2013) have distinguished between Capital C and small c cultures. Kramsch argues that Big C culture is "the hallmark of the cultivated middle-class" and "the culture traditionally taught with standard national languages." This includes "teaching about the history, the institutions, the literature and the arts of the target country [...] bound up with notions of the 'good' and 'proper' way of life" (2013, p.66). In other words, Big C culture incorporates the nation's record of its historical, cultural, literary, political, and economic heritage. Small c culture, on the other hand, "includes the native speakers' ways of behaving, eating, talking, dwelling, their customs, their beliefs and values". This highlights "the sociolinguistic appropriateness of language" (Kramsch, 2013, p.67), and teaching culture is gaining its deserving place in language learning and pedagogy (Baker, 2011). According to Richards and Schmidt,

The cultural dimension of language learning is an important dimension of second language studies. Education is seen as a process of socialization with the dominant culture. In foreign language teaching the culture of the language may be taught as an integral part of the curriculum. (2010, p. 151)

Kramsch also observes that,

Despite the considerable amount of research dedicated to defining the nature, importance and place of culture in foreign language study (see e.g., Byrnes, 2002;Kramsch 1993, 1997, 1998; Lange \& Paige, 2003; Risager, 2006, 2007), culture remains a hotly debated issue in the teaching of foreign languages around the world. The debates involve school curricula, language teachers and language learners. (2013, p. 58)

In this regard, numerous studies in the literature argue that language and culture are interrelated (Dai, 2011; Heileman\& Kaplan, 1985; Kramsch, 1998; Peck, 1998; Savignon\&Sysoyev, 2002; Sellami, 2000; Zhao, 2010; Thanasoulas, 2001), and that they are best acquired together (Schulz, 2007). Therefore, teaching culture in the EFL classroom is often regarded as an integral component of most language courses (Brown, 2000).

Various justifications have been proposed for the significance of culture in second/ foreign language learning. According to Gence and Bada (2005) teaching L2 is erroneous and incomplete if L2 students know little about the people who speak the target language or the country in which the target language is spoken, language learning will seem senseless. Byram and Flemming (1998) also declare that target language culture should be taught along with the other four skills. Pulverness (2003) suggests that language may seem senseless for foreign language learners if they know nothing about the people who speak the target language. McDevitt (2004) argues that it is impossible to imagine learning another language disregarding its culture, since learning a foreign languageremains a challenge as it explores the norms, habits, and values cherished by the speakers of the target language. As language reflects cultural norms, studying language inherently exposes learners to the target culture. According to Gao (2006), "the interdependence of language learning and cultural learning is so evident that one can conclude that language learning is culture learning and consequently, language teaching is cultural teaching" (p.59). Gaoalso argues that foreign language teachers should consider the place of cultural studies in foreign language classroom and try to enhance students' cultural awareness and improve their communication competence. Wang (2008) believes that, "foreign language teaching is foreign culture teaching, and foreign language teachers are foreign culture teachers" (p.4).

Silberstein (2001) believes that grammatical knowledge is not enough to guarantee good and appropriate communication. Teaching a language is more than teaching its grammar, phonology, and lexis. Teaching cultural norms in a non-judgmental way is of prime significance. Linguistic competence alone is not enough for learners of a language to be competent in that language (Krasner, 1999).

\subsection{Cultural Intelligence}

The notion of cultural intelligence has been described as a "new kid on the block"(Gelfand, Imai \& Fehr, 2008, p.376).Cultural intelligence is defined as the capability to function effectively in culturally diverse contexts (Ang\& Van Dyne, 2008; Earley\&Ang 2003); it is "a set of capabilities comprising mental, motivational and behavioral components that focus specifically on resolving cross-cultural problems" (Ng, Van Dyne \&Ang, 2012. p. 29). Cultural intelligence is regarded as essential for effective business and successful engagement in any environment or social setting (Ang, Van Dyne, Koh, Ng, Templer, Tay, \&Chandrasekar, 2007). Therefore, knowledge of one's cultural intelligence provides insights into one's capability to cope with multicultural situations. It also demonstrates how one engages in crosscultural interactions as well as how one performs effectively in culturally diverse settings. The concept of CQ was examined by (Early, 2002; Early \&Ang, 2003) to explore the individuals' differences in effectively communicating across cultures. According to Early \&Ang (2003), having a high level of cultural intelligence means that individuals are more able to extract and logically interpret information gathered from cross cultural interactions, and are more flexible 
in adjusting to different settings. Early and Ang's (2003) conceptualization of CQ is based on Sternberg's (1986) multiple-loci-of-intelligence framework. They argued that CQ is comprised of metacognitive, cognitive, motivational, and behavioral dimensions which impact functioning in culturally diverse settings.

Meta-cognitive CQ is defined as "an individual's cultural consciousness and awareness during intercultural interactions. Metacognitive CQ focuses on higher-order cognitive processes, and involves capabilities to plan, monitor, and revise mental models of cultural norms" (Koh, Joseph, \& Ang, 2009, p. 8). Cognitive CQ refers to “a person's knowledge and understanding of how cultures are similar to and different from each other" (Khodadady \& Ghahari, 2011, p.66).Motivational CQ refers to a person's high ability, motivation, and interest to learn and function confidently in culturally diverse situations (Bandura, 2002). Behavioral CQ is a person's capability to show proper verbal and nonverbal conduct when interacting with people from different cultures.

\subsection{Listening Ability and Culture}

According to Bakhtiarvand and Adinevand (2011), culture is "an inseparable part of the way in which we live our lives and the way we use language, [and] an important requirement for learning spoken English, is the acquisition of cultural knowledge"(p.112).With respect to listening comprehension, which is the focus of the current study, there is an overall consensus among the researchers on the considerable role of prior and cultural knowledge (Muller, 1980; Othman \&Vanathas, 2004;Sadeghi\&Zare, 2002). Sadighi and Zare (2002) have explored the effect of background knowledge on listening comprehension. The participants in their study were two TOEFL preparation classes allocated to EFL learners. The experimental group received some treatment in the form of topic familiarity, and their background knowledge was activated. Then a 50-item TOEFL test of listening comprehension was administered to both experimental and control groups. A statistical analysis of the results provided some evidence in support of the effect of background knowledge on listening comprehension.

Gebhard (2000) proposes that background knowledge relates to one's real world experiences and expectations. This knowledge is very important when we consider the language processing problems of students. Listening then is not only concerned with identifying the linguistic features of the text but also with matching speech with what the listener already knows about the topic. He further adds that in the process of listening, comprehension can only occur when the listener can place what he hears in a context. If the listener knows something about the speakers and his intention, comprehension is much easier. Familiarity with the topic makes listening easier for the listener as he is able to relate to his own background knowledge.

\section{Objectives of the Study}

This study investigates the relationship between Iranian EFL Learners' Cultural intelligence (CQ) and their performance on the IELTS Listening Module.

\subsection{Research Questions}

1) Is there a significant relationship between Iranian EFL learners' cultural intelligence and their performance on the IELTS Listening Modules?

2) To what extent do components of CQ predict EFL learners' performance on the IELTS listening Modules?

\section{Methodology}

\subsection{Participants and Settings}

The subjects of this study included 60 advanced students (both male and female) who were selected via a standard test (Oxford Quick Placement Test). Their age ranged from 19 to $24(\mathrm{M}=21.5$ and $\mathrm{SD}=1.87)$. They were homogenous in terms of major (they also had listening course during the semester, English education background, and proficiency level (i.e. advance). They were all native speakers of Persian.

\subsection{Instrumentation}

The present study used two sets of instruments: 1) An IELTS listening test, and 2) The 20-item four-factor CQs Test (or the CQ Scale). To gather the required information on the subjects' performance on listening, an IELTS Listening test extracted from IELTS Master class by Harris and May (2008) was used. It included four parts. Each part consisted of a number of recorded conversations. The test was consisted of 40 questions. Each item was assigned a score of one. The reliability of IELTS scores, based on Cronbach Alpha was 0.912.

The second instrument was the Cultural Intelligence Scale. Cultural Intelligence Scale (The CQS) is rated on a fivepoint Likert-type scale ranging from 1 (strongly agree) to 5(strongly disagree). It took the students approximately 10 minutes to complete the test. The test provided a total score of CQ ranging from 41 to 101 . In order to increase the participants' comprehension of the questions and avoid misinterpretation of the statements, the Persian version of the CQ items was employed. Using Cronbach Alpha formula, the reliability of the CQ test was estimated to be 0.82 .

\subsection{Data Collection Procedure}

As mentioned above, in this study 3 questionnaires were used: Oxford Quick Placement Test, IELTS Listening Test, and Cultural Intelligence Sale (2007). The questionnaires were administered in two sessions. In the first session a proficiency test (Oxford Quick Placement Test) was administered in order to homogenize participants in terms of their proficiency level (i.e. advance level learners). They were instructed to code their answer sheets and use the same code in the second session. 
In the second session, the IELTS listening test was administered in the language laboratory. The participants listened to four recorded conversations. After each conversation, they were instructed to answer a set of questions. The completion of the listening comprehension test took approximately 60 minutes. Immediately afterwards the CQ scale was administered. It took around 15 minutes for the participants to answer the 20 questions of the CQ test.

\subsection{Data Analysis}

SPSS (version 16) was used to analyze the collected data. The reliability of the tests was estimated via Cronbach Alpha. Statistical analyses and both descriptive and inferential statistics were used to test the hypotheses:

HO 1: There is no significant relationship between Iranian EFL learners' cultural intelligence and their performance on the IELTS Listening Module.

H0 2: None of the factors of cultural intelligence can predict EFL learners' performance on the IELTS Listening Module.

\section{Results}

\subsection{Descriptive statistics}

Initially, descriptive statistics were computed for all instruments employed in this thesis. The results of descriptive statistics (i.e., mean, minimum, maximum and standard deviation) for continuous variables, namely, cultural intelligence and its four components (meta-cognitive, cognitive, motivational, behavioral CQs), and the IELTS listening test are displayed in Table1.

Table 1. Descriptive statistics for EFL learners' IELTS listening test and CQ

\begin{tabular}{cccccc}
\hline & $\mathrm{N}$ & Minimum & Maximum & Mean & Std. Deviation \\
\hline IELTS Test & 60 & 4 & 29 & 14.05 & 5.97 \\
\hline CQ & 60 & 41 & 101 & 69.57 & 9.80 \\
\hline $\begin{array}{c}\text { Meta-cognitive } \\
\text { CQ }\end{array}$ & 60 & 5 & 21 & 13.93 & 2.36 \\
\hline Cognitive CQ & 60 & & & 18.91 & 3.39 \\
\hline $\begin{array}{c}\text { Motivational } \\
\text { CQ }\end{array}$ & 60 & 11 & 30 & 18.78 & 3.68 \\
\hline Behavioral CQ & 60 & 5 & 26 & 19.43 & 19.03 \\
\hline
\end{tabular}

\subsection{Investigation the First Question}

The first question was meant to establish if there is a significant relationship between participants' CQ and their performance on the IELTS Listening test. A Pearson product-moment correlation coefficient was computed to assess the relationship between EFL learners' cultural intelligence and their performance on IELTS listening test. Table 2 shows the results of the analysis.

Table 2. Pearson correlation between IELTS Listening Test and CQ

\begin{tabular}{llrr}
\hline & CQ score & listening score \\
\hline \multirow{3}{*}{ CQ score } & Pearson Correlation & 1 & $.429^{*}$ \\
\cline { 2 - 4 } & Sig. (2-tailed) & .000 \\
\cline { 2 - 4 } & $\mathrm{N}$ & 60 & 60 \\
\hline
\end{tabular}

As indicated in Table 2, a significant positive correlation was found between CQ and IELTS Listening test. [r $=.42, \mathrm{n}=$ $60, \operatorname{sig}=.000, \mathrm{p}<.05]$. This correlation coefficient indicates a moderate relationship between CQ and IELTS Listening test. Thus the first null hypothesis is rejected and it is confirmed that there is a significant relationship between the learners' CQ and their performance on the IELTS listening test.

\subsection{Investigation the Second Question}

The second research question of the study dealt with the predictive power of CQ on EFL learners' performance on the IELTS Listening Module. In order to answer this question, the data was run through a multiple regression in which a stepwise method was applied in forming the regression models. In the current study, the listening scores were set as the dependent variable, whereas the four components of $\mathrm{CQ}$ (metacognitive CQ, cognitive CQ, motivational CQ, and behavioral CQ) were set as the independent predictor variables. Preliminary analyses were conducted to ensure nonviolation of the assumptions of normality ${ }^{1}$, linearity ${ }^{2}$ or multicollinearity ${ }^{3}$ (Figure 1 and Figure 2). 


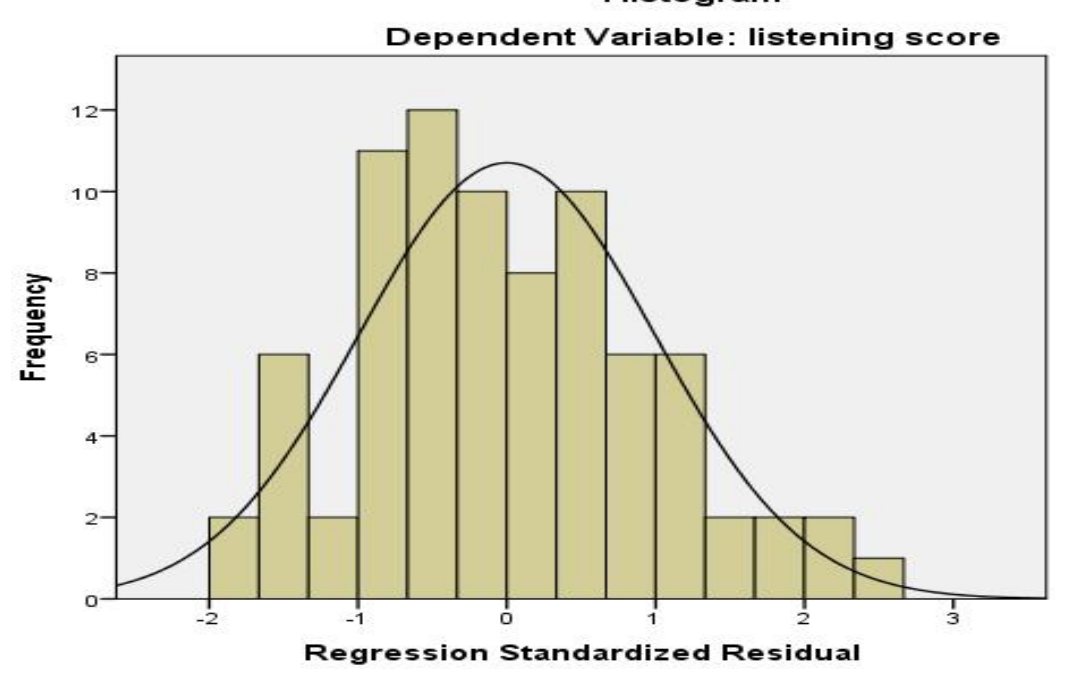

Figure 1

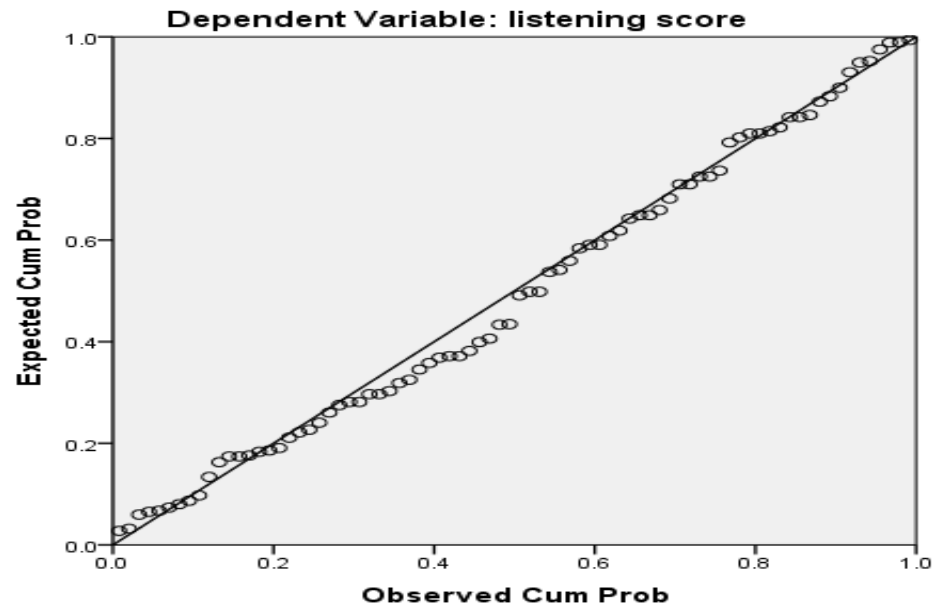

Figure 2

Table 3. Model Summary of Stepwise Multiple Regression

\begin{tabular}{lcccr}
\hline Model & $\mathrm{R}$ & $\mathrm{R}$ Square & Adjusted R Square & $\begin{array}{c}\text { Std. Error of the } \\
\text { Estimate }\end{array}$ \\
\hline 1 & .498 & .248 & .039 & 5.85839 \\
\hline
\end{tabular}

a. Predictors: (Constant), Motivational CQ score

Table 4. ANOVA Results

\begin{tabular}{lllllll}
\hline Model & & Sum of Squares & df & Mean Square & F & Sig. \\
\hline 1 & Regression & 144.782 & 1 & 144.782 & 4.219 & $.043^{\mathrm{a}}$ \\
\cline { 2 - 7 } & Residual & 2677.018 & 78 & 34.321 & & \\
\cline { 2 - 7 } & Total & 2821.800 & 79 & & & \\
\hline
\end{tabular}

a. Predictors: (Constant) Motivational CQ

b. Dependent variable: listening score

Table 3 reveals which variables are important in predicting higher score bands in the IELTS Listening Module. As indicated in Table 3, among the subscales of the CQ, motivational CQ is the best predictor of EFL learners' listening ability. Regression analysis showed R squared $=.248$ and according to Table 4, the results were significant (sig=.043, $\mathrm{p}<.05$ ). This proves that $24.8 \%$ of the variance of the listening achievement (dependent variable) is accounted for by the

1 -The data is normally distributed.

-There is a straight line relationship between the dependent and independent variables.

-There are no predictors in the model which are correlated and provide redundant information about the response. 
independent variable (motivational $\mathrm{CQ})$ in the model as indicated by the $\mathrm{R}$ squared $\left(\mathrm{R}^{2}=.248, \mathrm{p}<.05\right)$. In other words, $24.8 \%$ of variance of IELTS Listening scores can be explained by motivational CQ scores.

Table 5. Regression Coefficients ${ }^{\mathrm{a}}$ and Significance

\begin{tabular}{|c|c|c|c|c|c|c|}
\hline \multirow[b]{2}{*}{ Model } & & \multicolumn{2}{|c|}{ Unstandardized Coefficients } & \multirow{2}{*}{$\begin{array}{l}\text { Standardized } \\
\text { Coefficients } \\
\text { Beta }\end{array}$} & \multirow[b]{2}{*}{$\mathrm{t}$} & \multirow[b]{2}{*}{ Sig. } \\
\hline & & $\mathrm{B}$ & Std. Error & & & \\
\hline \multirow[t]{2}{*}{1} & (Constant) & 7.144 & 3.426 & & 2.085 & .040 \\
\hline & Motivational CQ & .368 & .179 & .227 & 2.054 & .043 \\
\hline
\end{tabular}

a. Predictors in the Model: (Constant), Motivational CQ score

Table 6. Excluded Variables ${ }^{\mathrm{b}}$

\begin{tabular}{|c|c|c|c|}
\hline Model & Beta In & $\mathrm{t}$ & Sig. \\
\hline $1 \quad$ Behavioral CQ & & & \\
\hline Cognitive CQ & $.137^{\mathrm{a}}$ & 1.144 & .256 \\
\hline Meta-cognitive CQ & $-.033^{\mathrm{a}}$ & -.254 & .800 \\
\hline
\end{tabular}

b. Dependent Variable: listening score

As shown in Table 5, one measured variable (factor) was included in the regression model that related to the listening achievement by advance EFL learners. $(\mathrm{B}=.368, \mathrm{t}=2.054$, sig $=.000, \mathrm{p}<.05)$. Also, Table 6 shows the statistics of variables which have been removed in the model (behavioral, sig=.593, $\mathrm{p}<.05$; cognitive $\mathrm{CQ}$, sig=.256, $\mathrm{p}<.05$; metacognitive $C Q$, sig=.800, $\mathrm{p}<.05)$.

\section{Conclusion and Discussion}

As the findings of this study reveal, EFL learners' cultural intelligence has a significant relationship with their performance on IELTS Listening Module. It means that those EFL learners who have higher CQ are more successful in the IELTS Listening Test and vice versa. This finding is in line with findings obtained in studies conducted by (Rafieyan, Golerazeghi \& Orang, 2015; Ghonsooly \& Shalchy 2013; Fatemi, Najafzade \& Sadeghzade, 2015), who found a strong positive relationship between cultural intelligence, pragmatic comprehension, speaking and writing ability, and job satisfaction, respectively. The results also confirm findings by Khodadady and Ghahari (2012), indicating that cultural intelligence as measured by CQS is negatively associated with TOEFL and its structure subtest. The findings conflict with Azizi, Fatemi, Pishghadam and Ghapanchi (2015), who found no significant relationship between CQ and total cultural attachment.

The results also indicated a significant positive relationship between the two components of CQ, namely, metacognitive and motivational CQs, and IELTS Listening Module performance. Metacognitive CQ essentially enables one to acquire knowledge and develop strategies to adapt to the new environment; it reflects the mental capacity to acquire and understand cultural knowledge. Those with higher metacognitive CQ are aware of others' cultural preferences before and during interactions ( $\mathrm{Ng} \&$ Early, 2006).

Successful listeners are able to interpret what is going on in the speakers' head as well as within the message and to make sense of culturally diverse settings and behaviors. Their higher level of metacognitive competence enables them to measure upon their cultural knowledge to make more sense of the different cultural context and handle it more effectively. This meta-competence equips them with the properties of awareness, planning, and checking, which are three sub-dimensions of metacognitive CQ. Through awareness, they come to realize that cultural differences exist between self and others. Finally, they are more likely to check and monitor if their expectations match what has culturally happened or communicated (Koh, Joseph \& Ang, 2009). The outcomes in the study, suggest that successful listeners are consciously aware of their own as well as others' cultural assumptions and values, deliberately plan for multicultural settings, and reflect and adjust their mental models accordingly.

Apart from metacognitive competence, motivational CQ was found to have relationship with EFL learners' performance on IELTS Listening Module. Individuals with high motivational CQ show interest, confidence, and drive to adapt cross-culturally. Successful listeners are motivated enough to face challenges, difficulties, and welcome social conflicts and contrasts.

The second research question was to find out which types of CQ have more predictive power in predicting the EFL learners' performance on IELTS Listening Module. Based on the findings, motivational CQ was found to be the best predictor of listening ability. This finding is in agreement with parallel studies by (Imai, 2007; Ghonsooly \&Golparvar, 2012; Peivandi, 2011) who found motivational CQ as the best predictor of writing ability and intercultural effectiveness respectively. Motivational CQ influences the achievement of language learners in listening comprehension tasks. Motivational competence mirrors the ability of directing energy towards finding out and taking part in multicultural situations (Leung \& Ang, 2008). According to Gence and Bada (2005), one of the primary advantages of cultural discussions in language classes, is that they have always had a motivating effect on the language learner and the 
learning process. They offer learners, some assistance with noticing similarities and differences among diverse cultures. Having lived most of their lives in mono-cultural and monolingual environments, L2 students around the world are culture-bound individuals who tend to make inappropriate value judgments about their own as well as about others' culture. This can lead them to consider the native speakers of their target language "as very peculiar and even illmannered, which in turn, plays a demotivating role in their language learning process" (Gence \& Bada, 2005, p.75).

In an increasingly multicultural world, enhancing cultural awareness can lead to better results in the English classroom. The findings of this study, which showed a relationship between cultural intelligence and listening comprehension, may benefit teachers, researchers, and policy-makers and encourage them to incorporate lessons to increase the EFL student's cultural intelligence. Cultural awareness can aid more effective communication skills in a foreign context as well as real life situations.

\section{References}

Ang, S., \& Van Dyne, L. (2008). Handbook on cultural intelligence: Theory, measurement and applications. Armonk, NY: M.E. Sharpe.

Ang, S., Van Dyne, L., Koh, C. K. S., Ng, K. Y., Templer, K. J., Tay, C., \& Chandrasekar, N. A. (2007). Cultural intelligence: Its measurement and effects on cultural judgment and decision making, cultural adaptation, and task performance. Management and Organization Review, 3, 335-371.

Azizi, Z., Fatemi, A., Pishghadam, R. \& Ghapanchi, Z. (2015). Investigating the Relationship between Iranian EFL Learners' Cultural Intelligence and their Home Cultural Attachment. Mediterranean Journal of Social Sciences, 6(3).

Baker, W. (2012).From cultural awareness to intercultural awareness: culture in ELT.ELT Journal, 66(1).

Bakhtiarvand, M. \&Adinevand, S. (2011).Is Listening Comprehension Influenced by the Cultural Knowledge of the Learners? A Case Study of Iranian EFL Pre-intermediate Learners. RELC Journal, 42(2) 111-124.

Byram, M., \& Flemming, M. (1998). Language learning from an intercultural perspective. New York, NY: Cambridge University Press.

Bandura, A. (2002). Social cognitive theory in cultural context. Applied Psychology: An International Review, 512, 269-290.

Brislin, R., Worthley, R., \& MacNab, B. (2006). Cultural intelligence: Understanding behaviors that serve people's goals. Group \& Organization Management, 31(1), 40-55.

Brown, H. (2000).Principles and Language Learning and Teaching. White Plains, NY: Addison Wesley Longman.

Dai, L. (2011).Practical Techniques for Cultural-based Language Teaching in the EFL Classroom. Journal of Language Teaching and Research. 2(5), 1031-1036.

Earley, P.C. \&Ang, S. (2003). Cultural Intelligence: Individual Interactions across Cultures. Stanford, CA: Stanford University Press.

Fatemi, M.A., Najafzade, F. \& Sadeghzade, H. (2015). The Relationship between EFL Teachers' Cultural Intelligence and Job Satisfaction. International Journal of Language Learning and Applied Linguistics World, 8(1), 157-162.

Gao, F. (2006). Language is Culture - On Intercultural Communication. Journal of Language and Linguistics, 5(1), 5867.

Gebhard, J. (2000). Teaching English as a Foreign or Second Language: A Teacher Self-development and methodology Guide. United States of America: The University of Michigan Press.

Gelfand, M. J., Imai, L., \& Fehr, R. (2008). Thinking intelligently about cultural intelligence: The road ahead. In S. Ang\& L. Van Dyne (Eds.), Handbook of cultural intelligence: Theory, measurement, and applications. New York, NY: M. E. Sharpe.

Genc, B. \&Bada, E. (2005).Culture in Language Learning and Teaching. The Reading Matrix, 5(1).

Ghonsooly, B. \& Golparvar, S.E. (2013). Probing the Predictive Power of Cultural Intelligence on Iranian EFL Learners' Performance on IELTS Writing Test. Studies in Applied Linguistics, 3(2).

Ghonsooly, B. \& Shalchy, Sh. (2013).Cultural intelligence and writing ability: delving into fluency, accuracy and complexity. Research on Youth and Language, 7(2), 147-159.

Giroux, H. A. (2000). Impure acts: The practical politics of cultural studies. London: Routledge.

Harris, S. \& May, P. (2008). IELTS Masterclass. London: Oxford University Press.

Heileman, L.K. \& Kaplan, I.M. (1985). Proficiency in Practice: the Foreign Language Curriculum. In C.J. James (Ed.), Foreign Language Proficiency in the Classroom and Beyond. Lincolnwood, Illinois: National Textbook Company.

Imai, R. (2007).The Culturally Intelligent Negotiator: The Impact of CQ on Intercultural Negotiation Effectiveness (Master Thesis).Retrieved 20 November 2015. 
Khodadady, E \&Ghahari, S. (2011). Validation of the Persian Cultural Intelligence Scale and Exploring Its Relationship with Gender, Education, Travelling Abroad and Place of Living. Global Journal of Human Social Science, 11(7).

Koh, C., Joseph, D., \&Ang, S. (2009). Cultural intelligence and global IT talent. In H. Bidgoli (Eds.), The Handbook of Technology Management (Volume 3). New York, NY: John Wiley \& Sons.

Kramsch, C. (1998). Language and culture. Oxford: Oxford University Press.

Kramsch, C. (2013). Culture in foreign language teaching. Iranian Journal of Language Teaching Research 1(1), 57-78

Krasner, I. (1999). The role of culture in language teaching. Dialog on Language Instruction, 13(1), 79-88.

Leung, K., \&Ang, S. (2008). Culture, organizations, and institutions: an integrative review. In R. S. Bhagat \& R. M. Steers (Eds.) Handbook of Culture, Organizations and Work. New York: Cambridge University Press.

McDevitt, B. (2004). Negotiating the syllabus: A win-win syllabus. ELT Journal, 58(1), 3-9.

Mueller, G.A. (1980). Visual contextual cues and listening comprehension: an experiment. Modern Language Journal, 64(3), 335-40.

Ng, K.Y., Van Dyne, L., \& Ang, S. (2012). Cultural intelligence: A review, reflections, and recommendations for future research. In A.M. Ryan, F.T. Leong, \& F.L. Oswald (Eds.), Conducting multinational research: Applying organizational psychology in the workplace (pp. 29-58). Washington, DC: American Psychological Association

Ng, K.Y., \& Earley, P.C. (2006). Culture and intelligence: Old constructs, new frontiers. Group \& Organization Management, 31, 4-19.

Othman, J. \& Vanathas, C. (2004). Topic familiarity and its influence on listening comprehension. The English Teacher, 34(8), 19-32.

Peck, D. (1998). Teaching Culture: Beyond Language. Retrieved 29 September 2015.http://www.yale.edu/ynhti/curriculum/units/1984/3/84.03.06.x.html

Peivandi, A. (2011). The Relationship between CQ and IQ in Writing Ability of Adult Iranian EFL Learners (master's thesis). Ferdowsi University of Mashhad.

Pulverness, A. (2003). Distinctions \& dichotomies: Culture-free, culture-bound. Retrieved 15 September.

https://www.academia.edu/268755/Distinctions_and_Dichotomies_Culture-Free_Culture-Bound.

Rafieyan, V., Golerazeghi, H. \&Orang, M. (2015). Relationship between Cultural Intelligence and Pragmatic Comprehension. Journal of Language Teaching and Research, 6(3), 560-565.

Richards, J. C. \& Schmidt, R. (2010). Longman dictionary of language teaching and applied linguistics. Malaysia: Pearson Education Limited.

Sadighi, F \& Zare, S. (2002). Is listening comprehension influenced by the background knowledge of the learners? A case study of Iranian EFL learners. The Linguistics Journal, 1(3), 110-26.

Saluveer, B. (2004). Teaching culture in English classes. (Master's thesis). University of Tartu

Savignon, S. \& Sysoyev, P. V. (2002). Sociocultural strategies for a dialogue of cultures. The Modern Language Journal, 86(4), 510-524.

Sellami, A.B. (2000). Teaching towards cultural awareness and intercultural competence: From What through How to Why culture is?ERIC. Paper presented at the Annual Meeting of Teachers of English to Speakers of Other Languages (Vancouver, BC, Canada.

Schulz, R. A. (2007). The challenge of assessing cultural understanding in the context of foreign language instruction. Foreign Language Annals, 40(1), 9-26.

Silberstein, S. (2001). Sociolinguistics. In R. Carter \& D. Nunan (Eds.), The Cambridge guide to teaching English to speakers of other languages (pp. 101-106). Cambridge, UK: Cambridge University Press.

Sternberg, R. J., \& Detterman, D. (1986). What is intelligence: Contemporary viewpoints on its nature and definition. Norwood: Ablex.

Thanasoulas, D. (2001). The Importance of Teaching Culture in the Foreign Language Classroom. Radical Pedagogy Journal, 3(3).

Triandis, H.C. (2006). Cultural Intelligence in Organizations. Group \& Organization Management, 31(1), $20-26$.

Wang, X.-y. (2008). Reflection on the notion of culture teaching. US-China Foreign Language Journal, 6(1), 49-53.

Zhao, B. (2010).How to Enhance Cross-cultural Awareness in TEFL. Cross-cultural communication, 6(2), $100-104$. 